\title{
ОЦІНКА НАДІЙНОСТІ ТА ІНФОРМАТИВНОСТІ ПОКАЗНИКІВ КООРДИНАЦІЙНОЇ ПІДГОТОВЛЕНОСТІ ХЛОПЧИКІВ 8 РОКІВ
}

\author{
Світлана Марченко ${ }^{1 \mathrm{ABCD}}$, Ярослав Вердиш $^{1 \mathrm{ABCD}}$ \\ ${ }^{1}$ Харківський національний педагогічний університет імені Г.С. Сковороди \\ Authors' Contribution: A - Study design; B - Data collection; C - Statistical analysis; D - Manuscript Preparation; E - Funds Collection
}

DOI: $10.17309 /$ jltm.2021.1.03

\begin{abstract}
Анотація
Мета дослідження - розробка програми тестування координаційної підготовленості школярів на початковому етапі тренування з використанням інформативних тестів, які доступні для застосування в умовах загальноосвітньої школи.

Матеріали і методи. У дослідженні взяли участь 20 хлопців 8 років. Діти та їхні батьки були інформовані про всі особливості дослідження і дали згоду на участь в експерименті. Для вирішення поставлених завдань були застосовані такі методи дослідження: аналіз науково-методичної літератури, педагогічне тестування та методи математичної статистики обробки результатів дослідження.

Результати. Запропонована батарея тестів усебічно характеризує розвиток координації хлопчиків 8 років. У результаті аналізу кореляційної залежності між тестовими завданнями встановлено їх високу валідність $\left(\mathrm{r}_{\mathrm{xy}}=0,575-0,931\right.$ при $\left.\mathrm{p}<0,01\right)$. Обрані нами тести мають добру та відмінну ретестову надійність $\left(\mathrm{r}_{\mathrm{tt}}=0,92-\right.$ 0,989). Комбінований тест, який включає в себе як загальні рухові дії, так і елементи карате, має високий ступінь достовірності вимірювання та може замінювати цілу батарею тестів $\left(\mathrm{r}_{\mathrm{tt}}=0,979\right)$.

Висновки. Отримані дані дають підставу стверджувати, що обране комплексне тестування рівня розвитку проявів координаційних здібностей хлопчиків 8 років під час занять карате $\epsilon$ доступним, інформативним та надійним, що дає можливість їх рекомендувати для подальшого дослідження в процесі вдосконалення рухової координації.
\end{abstract}

Ключові слова: хлопці, координаційна підготовленість, надійність і інформативність тестів, кіокушинкай карате.

\section{Вступ}

На сьогодні відбувається значне омолодження контингенту спортсменів початківців. Згідно 3 наказом Міністерства молоді та спорту України від 10.11.2017 №4706 мінімальний вік вихованців, які зараховуються до груп відділень з неолімпійських видів спорту комплексних дитячо-юнацьких спортивних шкіл, дитячо-юнацьких спортивних шкіл з виду спорту кіокушинкай карате складає 6 років. На практиці в Україні та за їі межами спостерігається тенденція залучення до занять у спортивних секціях навіть дітей дошкільного віку. У наукових працях Malina (2010), Jayanthi, Pinkham, Dugas, Patrick and LaBella (2013), Платонова (2015) вказується, що для кожного виду спорту існує оптимальний вік початку тренувальних занять. Американські вчені Jayanthi, Pinkham, Dugas, Patrick \& LaBella (2013) демонструють, що рання спеціалізація збільшує ризик травм на 70\%, а зайве навантаження при-

(c) Марченко, С., Ярослав Вердиш, Я., 2021. зводить до хронічної втоми і перенавантаження дитини, що може привести до затримки розвитку. Травматизм у дітей нерідко призводить до неможливості продовження тренувань і відмови від зайняття спортом.

В ідеалі необхідна не рання і поглиблена спеціалізація в конкретному виді спорту, а створення основи для прояву оптимальної моторики дитини. Під оптимальною моторикою слід розуміти фізичну культуру, а засобами вирішення поставленої задачі - рухи які загально розвивають. На думку Chaabene, Hachana, Franchini, Mkaouer and Chamari (2012) фундаментальні рухові навички (біг, стрибки, ведення і ловля м'яча та інші) тісно пов'язані з координаці$€ ю$ та $є$ важливими для досягнення максимального рівня спортивних показників у дорослих спортсменів.

Щоб запобігти ранньої спеціалізації та надалі популяризувати карате, Словацький союз карате розробив нову змагальну дисципліну «Спритне карате» для дітей 5-7 та 8-11 років (Slovensky zvaz karate, 2017). Діти діляться відповідно до статі, віку та вагових категорій як у куміте (поєдинок). 
Для школярів, які займаються кіокушинкай карате, $\epsilon$ необхідним високий рівень координаційних здібностей. Оскільки від ступеня їх розвитку залежить успішність навчання новим руховим діям і можливість раціонально проводити технічнудію. Які раніше дискусійними залишаються питання діагностики координаційних здібностей.

Однією із найбільш складних проблем тестування $\epsilon$ його математичне забезпечення. Найбільш загальними властивостями, що визначають придатність тесту до практичного використання є: складність, тривалість, абсолютна і відносна надійність та інформативність. Ці аспекти необхідно враховувати під час складання батареї тестів карате (Зациорский, 1982; Chaabene, Hachana, Franchini, Mkaouer, Chamari, 2012).

Гостроту цьому питанню надає те, що у представників різних видів спорту існують свої ведучі, домінуючі координаційні здібності, що в першу чергу визначають результативність тренувальної і змагання діяльності. Тому для їх оцінки потрібні свої специфічні тестові завдання i технології діагностики, що об'єктивно відображають рівень розвитку спеціальних координаційних здібностей.

Мета дослідження - розробка програми тестування координаційної підготовленості школярів на початковому етапі тренування $з$ використанням інформативних тестів, які доступні для застосування в умовах загальноосвітньої школи.

\section{Матеріали і методи}

\section{Учасники дослідження}

У дослідженні взяли участь 20 хлопців 8 років. Діти та їхні батьки були інформовані про всі особливості дослідження і дали згоду на участь в експерименті.

\section{Організація дослідження}

Для вирішення поставлених завдань були застосовані такі методи дослідження: аналіз науково-методичної літератури, педагогічне тестування та методи математичної статистики обробки результатів дослідження.

\section{Прочедури тестування}

Програма тестування координації базувалася на аналізі змагань з карате. Враховувалось також те, що тест повинен бути простим у використанні, недорогим, без застосування спеціальних технічних пристроїв, безпечним та цікавим для дітей. Тестування проводилось змагальним методом. Під час змагань використовували засоби контролю загальної та спеціальної координації. А також основні техніки, що найбільш застосовуються в змаганнях карате (цукі чудан та чудан має гері). Для встановлення надійності тестів, учасники двічі виконували тести з максимальними зусиллями, з інтервалом у тиждень, за одних умов (Hopkins, 2000). У програму тестування ввійшли загальновідомі тести Сергієнко (2010), Худолій \& Іващенко (2011), Рогожников (2016), Slovensky zvaz karate (2017). Тести для оцінки спеціальної координації «Дзеркало» та«Квачі» побудовані на основі вправ 3 класичного боксу і одноборств.
Тести для оцінки загальної координації.

Тест 1. Стрибки з «надбавками».

Обладнання. Обладнаний сектор для стрибків; крейда; калькулятор; рулетка.

Проведення тесту. Для кожного учасника тестування визначають максимальний результат у стрибках у довжину з місця. Потім за допомогою калькулятора обчислюють 50 і 75\% максимального стрибка. Креслять на відстані 50\% максимального результату стрибка першу лінію. Для кращого орієнтування збоку встановлюють кубик. На відстані 75\% максимального результату стрибка накреслюють другу лінію. Тим самим визначають індивідуальний коридор стрибків з «надбавками».

Потім у межах даного коридору досліджувані виконують стрибки 3 «надбавками». Підрахунок надбавок припинявся, як тільки досліджуваний досягнув другої лінії, або якщо у двох стрибках, виконаних підряд, не збільшив довжину стрибка.

Результат. Кількість стрибків з «надбавками», що виконані у заданому коридорі.

Загальні вказівки та зауваження.

1. Виконувати стрибки з жорстким приземленням забороняється.

2. Для визначення максимального результату стрибка надається три спроби. Стрибки з «надбавками» виконуються два рази.

3. Для кращого розуміння виконання тесту надається попередня спроба.

Тест 2. Човниковий біг $4 \times 9$ м.

Обладнання. Секундомір і рівна доріжка довжиною 9 м, обмежена двома паралельними лініями. За кожною лінією знаходяться 2 півкола радіусом 50 см $з$ центром на лінії. Два дерев'яних кубика $(5 \times 5 \times 5$ см).

Проведення тесту. За командою «На старт!» учасник тестування стає у положення високого старту перед стартовою лінією. За командою «Марш!» у максимальному темпі пробігає 9 м до другої лінії, бере один із двох дерев'яних кубиків, що лежать у півколі, бігом повертається назад і кладе його в стартове півколо (кидати кубик не можна), знову біжить у зворотному напряму, повертається з другим кубиком і кладе його у стартове півколо. На цьому тест закінчується.

Результат. Час, зафіксований 3 точністю до 0,1 с 3 моменту старту до моменту, коли учасник поклав другий кубик у півколо.

Загальні вказівки та зауваження.

1. Кожному учаснику надається дві спроби. До протоколу заносять кращий або середній результат, розрахований із двох спроб.

2. Спроба не зараховується, якщо випробовуваний кидає або впускає кубик у півколо. Його слід акуратно покласти. Якщо ця вимога не виконується, то надається повторна спроба.

3. Доріжка, на якій проводиться човниковий біг, має бути рівною, у хорошому стані, не слизькою.

Тест 3. Вправи на поєднання рухів руками, тулубом, ногами.

Виконувались для визначення здатності до виконання складних за координацією рухів. Одночасно різнонаправлені рухи руками при ходьбі.

Обладнання. Спортивний майданчик або зала. 
Проведення тесту. Після показу і 2-3 повторень учні виконують наступні вправи: в.п. - о.с. 1 - крок лівою, руки - праву вперед, ліву в сторону; 2 - в.п.; 3 - крок правою, руки - ліву вперед, праву в сторону; 4 - в.п. вправу повторити 4 рази підряд.

Результат. Кількість допущених помилок, впевненість і чіткість виконання вправи.

Загальні вказівки й зауваження. Рухи повинні бути злитими і точними. При відхиленні рук від указаних положень більше $30^{\circ}$, порушення постави, неузгодженості в рухах рук і ніг завдання вважається не виконаним.

Тест 4. Стійка на одній нозі з закритими очима.

Обладнання. Секундомір.

Проведення тесту. За командою учасник приймає вихідне положення - стійка на одній нозі, інша зігнута та торкається п'ятою колінного суглоба, стегно відведено в сторону, руки на пояс. Відлік часу починається по секундоміру, який вмикається в момент, коли учень закриває очі.

Результат. Час від включення секундоміру до втрати рівноваги.

Загальні вказівки й зауваження. Учень повинен виконувати вправу з повністю закритими очима, а не примружувати ї. Коліно відводити чітко в сторону. Вихідне положення приймається з відкритими очима.

Тести для оцінки спеціальної координації.

Тест 5. «Дзеркало».

Обладнання. Секундомір.

Проведення тесту. Два учасники стають один проти одного на відстані 2 метри. Один з них виконує в середньому темпі рухи у будь-якому порядку вперед-назад, вправо-вліво, руками і ногами, а також може виконувати захисні дії, імітувати удари. Другий учасник зображує «Дзеркало» - він повинен точно повторювати якомога точніше усі дії. Вправа виконується впродовж 15 секунд.

Результат. Кількість допущених помилок за відведений час.

Загальні вказівки та зауваження. Помилкою вважається: неправильний початок руху, помітна затримка руху, зупинка руху. Дається одна спроба. Спочатку усі випробовувані апробують цей тест.

Тест 6. «Квачі».

Обладнання. Секундомір.

Проведення тесту. Вправа виконується у парах. Один з учасників в середньому темпі намагається зачепити за певну частину тіла випробовуваного (голова, плечі, живіт) долонями. Другий (випробовуваний) повинен виконувати захисні дії, підставки, відходи, закривати тулуб ліктями без завдання ударів у відповідь. Вправа виконується 15 секунд.

Результат. Кількість пропущених торкань.

Загальні вказівки та зауваження. Дається одна спроба.

Тест 7. Нанесення на швидкість бокових ударів ногами по ракетках з партнером оббігаючи конуси «змійкою».

Обладнання. Татамі (площа $8 \times 3 \mathrm{~m}^{2}$ ), вимірювальна стрічка, 3 конуси, 2 ракетки, секундомір.

Проведення тесту. На відстані 8 м по прямій лінії встановлюються три конуси, з яких перший - на відстані 2 м від лінії старту, а два наступні на такій же відстані один від одного. Випробовуваний стає на лінію старту разом з помічником, який тримає в руках два снаряди (ракетки). За сигналом випробовуваний долає відстань 8 м, наносячи по черзі на швидкість бокові удари ногами в середній рівень, до лінії фінішу, рухаючись «змійкою». Час зупиняється, коли випробовуваний повністю перетинає лінію фінішу.

\section{Результат.}

1. Час, за який випробовуваний долає відстань, зафіксований $з$ точністю до $0,1 \mathrm{c}$.

2. Кількість завданих ударів випробовуваним під час виконання тесту (разів).

3. Коефіцієнт результативності, відношення кількості завданих ударів на час (Крез).

Загальні вказівки та зауваження.

1. Обов'язково дотримуватись техніки виконання удару.

2. Зараховуються тільки точні попадання.

Тест 8. Комплексний тест.

Обладнання. Татамі (площа $7 \times 7=42 \mathrm{~m}^{2}$ ), 9 гумових стрічок, 18 конуси, 4 пластикові тарілки, 3 тенісних м’яча, секундомір.

Проведення тесту. Учасник стартує за звуковим сигналом з положення сидячи на підлозі, ноги разом, п'ятки на лінії старту. Після старту учасник біжить навколо конуса, далі продовжує біг спиною вперед, після чого оббігає чотири стійки «змійкою», виконує чотири удари руками і чотири удари ногами, виконує десять стрибків через бар'єри висотою 10-12 см (5 на одній нозі в одну сторону і 5 на другій нозі у зворотному напрямку). На заключному етапі учасник перекладає тенісні м'ячі з однієї пластикової тарілки в іншу. Коли учасник кладе останній тенісний м'яч на тарілку розташовану на фінішній лінії, відлік часу зупиняється (рис. 1).

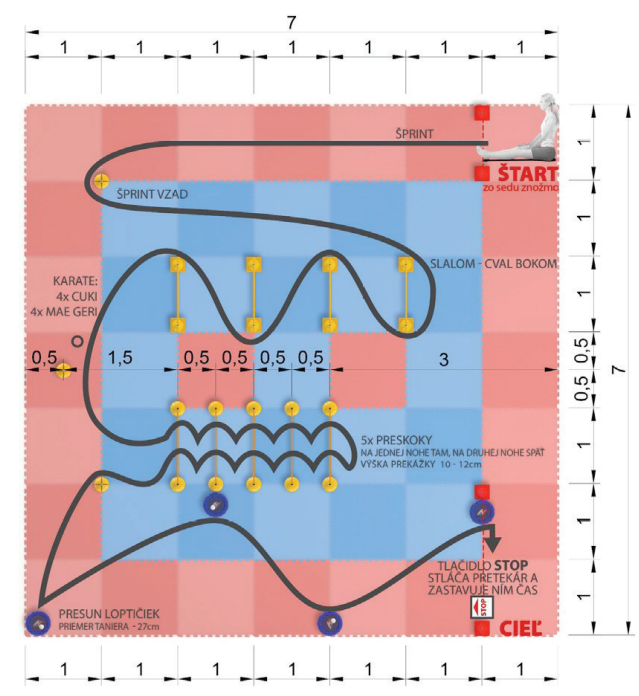

Рис. 1. Схема змагального майданчика (Source: Slovensky zvaz karate, 2017)

\section{Результат.}

Час, за який випробовуваний долає дистанцію, зафіксований $з$ точністю до $0,1 \mathrm{c}$.

Назначаються наступні покарання.

Штраф 0,3 с за: контакт із перешкодою; незначну помилку; за пропущення удару рукою або удару ногою $(0,3$ секунд для кожної пропущеної техніки); за торкання гумової стрічки. 
Штраф 0,5 с за: неправильна техніка стрибків; неправильна техніка приставного кроку.

Штраф 1 с за: пропуск перешкоди; перекидання перешкоди; якщо тенісний м’яч випадає з тарілки, або учасник губить м'яч (кожен загублений м'яч карається окремо).

Загальні вказівки та зауваження.

Тест проводиться в найкоротший термін без технічної помилки.

Учасник змагань дискваліфікується, якщо якесь із завдань пропущене.

(Source: Slovensky zvaz karate, 2017).

\section{Статистичний аналіз}

Дані були зібрані та організовані за допомогою EXCEL. Статистичний аналіз проводився за допомогою статистичного програмного пакету IBM SPSS Statistics 26. Обчислювались такі параметри: середнє арифметичне значення величини (X), стандартне відхилення, коефіцієнт кореляції Пірсона (rху). Гіпотеза про нормальність розподілу даних визначалась за допомогою критерію Шапіро-Уілка (W). Розраховувався коефіцієнт надійності (rtt) за допомогою внутрішньокласового коефіцієнта кореляції між двома рядами результатів, отриманих під час першого і другого тестування групи школярів (формула Спірмена-Брауна).

\section{Результати дослідження}

У таблицях 1-4 наведені результати аналізу показників координаційної підготовленості хлопчиків 8 років. Усі результати за більшістю середньостатистичних показників відповідають закону нормального розподілу.

Гіпотеза про нормальність розподілу даних визначалась за допомогою критерію Шапіро-Уілка (табл. 2). У всіх тестах гіпотеза про нормальність розподілу даних приймається. У тесті «Вправи на поєднання рухів руками, тулубом, ногами» гіпотеза про нормальність розподілу даних відхиляється $\mathrm{p}<0,001$. У даному випадку, щоб використати цей тест для визначення здатності до виконання складних за координацією рухів, необхідно збільшити кількість спостережень і повторити дослід.
Таблиця 2. Нормальність розподілу даних за критерієм Шапіро-Уілка

\begin{tabular}{lccc}
\hline \multirow{2}{*}{ Тест } & \multicolumn{3}{c}{ Критерій Шапіро-Уілка } \\
\cline { 2 - 4 } & Статистика & ст.св. & знач. \\
\hline Тест 1 &, 905 & 20 &, 052 \\
Тест 2 &, 988 & 20 &, 993 \\
Tест 3 &, 780 & 20 &, 000 \\
Тест 4 &, 926 & 20 &, 131 \\
Тест 5 &, 934 & 20 &, 188 \\
Тест 6 &, 941 & 20 &, 248 \\
Тест 7 &, 961 & 20 &, 569 \\
Тест 8 &, 967 & 20 &, 686 \\
\hline
\end{tabular}

Аналіз кореляційної залежності між тестовими завданнями показує сильний взаємозв'язок високого ступеня значимості майже між усіма тестами $\left(\mathrm{r}_{\mathrm{xy}}=0,718\right.$ 0,931при $\mathrm{p}<0,001$ (табл. 3).

Середній взаємозв'язок високого ступеня значимості спостерігався у тестах «Стійка на одній нозі з закритими очима» $\mathrm{i}$ «Вправи на поєднання рухів руками, тулубом, ногами» $\mathrm{r}_{\mathrm{xy}}=0,575$ при $\mathrm{p}<0,008$; «Нанесення на швидкість бокових ударів ногами по ракетках з партнером оббігаючи конуси «змійкою» $\mathrm{i}$ «Вправи на поєднання рухів руками, тулубом, ногами» $\mathrm{r}_{\mathrm{xy}}=0,599$ при $\mathrm{p}<0,005$. Спостерігається тісний взаємозв'язок між результатами тестів, які характеризують загальну координацію з тестами на спеціальну координацію.

Слід відмітити, що комбінований тест, який включає в себе як загальні рухові дії, так і елементи карате, має високий ступінь достовірності вимірювання та може замінювати цілу батарею тестів.

Дані кореляції дають можливість проводити більш досконало процес відбору та організацію тренувального процесу новачків, метою якого $є$ підвищення якості фундаментальних рухових навичок, які на більш пізніх етапах стають основою вивчення техніки карате.

Валідність усіх обраних тестів, крім тесту «Вправи на поєднання рухів руками, тулубом, ногами», вказує на високу ефективність використання даної методики для вимірювання як загальної так і спеціальної координації.

Встановлення рівня надійності шляхом повторного тестування показало, що обрані нами тести мають різну

Таблиця 1. Результати розрахунку описової статистики

\begin{tabular}{|c|c|c|c|c|c|c|c|c|c|}
\hline \multicolumn{2}{|c|}{ Статистики } & Тест 1 & Тест 2 & Тест 3 & Тест 4 & Тест 5 & Тест 6 & Тест 7 & Тест 8 \\
\hline \multirow[t]{2}{*}{$\mathbf{N}$} & Валідні & 20 & 20 & 20 & 20 & 20 & 20 & 20 & 20 \\
\hline & Пропущені & $\mathbf{0}$ & 0 & $\mathbf{0}$ & $\mathbf{0}$ & $\mathbf{0}$ & $\mathbf{0}$ & $\mathbf{0}$ & $\mathbf{0}$ \\
\hline \multicolumn{2}{|c|}{ Середнє } & 3,55 & 12,43 & 8,875 & 6,65 & 5,95 & 7,2 & 1,49 & 25,36 \\
\hline \multicolumn{2}{|c|}{ Медіана } & 3,50 & 12,4 & 9,0 & 6,0 & 6,0 & 7,5 & 1,51 & 25,46 \\
\hline \multicolumn{2}{|l|}{ Мода } & $2^{\mathrm{a}}$ & $11,9^{\mathrm{a}}$ & 9,0 & $6^{\mathrm{a}}$ & 6 & 8 & $1,32^{\mathrm{a}}$ & $20,74^{\mathrm{a}}$ \\
\hline \multicolumn{2}{|c|}{ Стандартне відхилення } & 1,23 & ,93 &, 32 & 1,9 & 1,9 & 2,56 &, 18 & 2,18 \\
\hline \multicolumn{2}{|c|}{ Асиметрія } & ,246 &,- 076 & ,253 & ,255 &,- 073 &,- 184 &,- 247 &,- 317 \\
\hline \multicolumn{2}{|c|}{ Стандартне відхилення асиметрії } &, 512 &, 512 &, 512 &, 512 &, 512 &, 512 &, 512 &, 512 \\
\hline \multicolumn{2}{|c|}{ Ексцес } &,- 949 & ,124 &,- 439 &,- 930 &,- 872 & $-1,053$ &,- 840 &,- 063 \\
\hline \multicolumn{2}{|c|}{ Стандартна помилка ексцесу } & ,992 & ,992 & ,992 & ,992 & ,992 & ,992 & ,992 & ,992 \\
\hline \multicolumn{2}{|c|}{ Мінімум } & 2 & 10,4 & 8,5 & 4 & 3 & 3 & 1,17 & 20,74 \\
\hline \multicolumn{2}{|c|}{ Максимум } & 6 & 14,2 & 9,5 & 10 & 9 & 11 & 1,82 & 28,84 \\
\hline
\end{tabular}

а. Існує кілька модальних значень. Показано найменше значення 
Таблиця 3. Кореляційна залежність між тестовими завданнями

\begin{tabular}{|c|c|c|c|c|c|c|c|c|c|}
\hline \multicolumn{10}{|c|}{ Кореляції } \\
\hline & & Тест 1 & Тест 2 & Tест 3 & Тест 4 & Тест 5 & Тест 6 & Тест 7 & Тест 8 \\
\hline \multirow[t]{2}{*}{ Тест 1} & Кореляція Пірсона & 1 & & & & & & & \\
\hline & Знач. (двостороння) & & & & & & & & \\
\hline \multirow[t]{2}{*}{ Тест 2} & Кореляція Пірсона &,$- 851^{* *}$ & 1 & & & & & & \\
\hline & Знач. (двостороння) &, 000 & & & & & & & \\
\hline \multirow[t]{2}{*}{ Тест 3} & Кореляція Пірсона &, $718^{* *}$ &,$- 720^{* *}$ & 1 & & & & & \\
\hline & Знач. (двостороння) &, 000 &, 000 & & & & & & \\
\hline \multirow[t]{2}{*}{ Тест 4} & Кореляція Пірсона &, $872^{* *}$ &,$- 807^{* *}$ &, $575^{* *}$ & 1 & & & & \\
\hline & Знач. (двостороння) &, 000 &, 000 &, 008 & & & & & \\
\hline \multirow[t]{2}{*}{ Тест 5} & Кореляція Пірсона &,$- 838^{* *}$ &, $886^{* *}$ &,$- 833^{* *}$ &,$- 776^{* *}$ & 1 & & & \\
\hline & Знач. (двостороння) &, 000 &, 000 &, 000 &, 000 & & & & \\
\hline \multirow[t]{2}{*}{ Тест 6} & Кореляція Пірсона &,$- 867^{* *}$ &, $802^{* *}$ &,$- 738^{* *}$ &,$- 805^{* *}$ &, $895^{* *}$ & 1 & & \\
\hline & Знач. (двостороння) &, 000 &, 000 &, 000 &, 000 &, 000 & & & \\
\hline \multirow[t]{2}{*}{ Тест 7} & Кореляція Пірсона &, $843^{* *}$ &,$- 881^{* *}$ &, $599^{* *}$ &, $806^{* *}$ &,$- 801^{* *}$ &,$- 810^{* *}$ & 1 & \\
\hline & Знач. (двостороння) &, 000 &, 000 &, 005 &, 000 &, 000 &, 000 & & \\
\hline \multirow[t]{2}{*}{ Тест 8} & Кореляція Пірсона &,$- 779^{* *}$ &, $757^{* *}$ &,$- 834^{* *}$ &,$- 756^{* *}$ & ,931 &, $853^{* *}$ &,$- 741^{* *}$ & 1 \\
\hline & Знач. (двостороння) &, 000 &, 000 &, 000 &, 000 &, 000 &, 000 &, 000 & \\
\hline
\end{tabular}

Таблиця 4. Кореляції парних вибірок

\begin{tabular}{llcccc}
\hline & 3міст & $\mathbf{N}$ & $\mathbf{r}$ & $\mathbf{p}$ & $\begin{array}{c}\text { Коефіцієнт } \\
\text { надійності }\end{array}$ \\
\hline Пара 1 & Тест 1 \& ретест 1 & 20 &, 851 &, 000 & 0,92 \\
Пара 2 & Тест 2 \& ретест 2 & 20 &, 979 &, 000 & 0,989 \\
Пара 3 & Тест 3 \& ретест 3 & 20 &, 598 &, 005 & 0,748 \\
Пара 4 & Тест 4 \& ретест 4 & 20 &, 882 &, 000 & 0,937 \\
Пара 5 & Тест 5 \& ретест 5 & 20 &, 863 &, 000 & 0,926 \\
Пара 6 & Тест 6 \& ретест 6 & 20 &, 923 &, 000 & 0,96 \\
Пара 7 & Тест 7 \& ретест 7 & 20 &, 876 &, 000 & 0,934 \\
Пара 8 & Тест 8 \& ретест 8 & 20 &, 959 &, 000 & 0,979 \\
\hline
\end{tabular}

але достатню ретестову надійність $\left(\mathrm{r}_{\mathrm{tt}}=0,75-0,989\right)$. Відмінну надійність виявлено у тестах «Човниковий біг $4 \times 9$ $\mathrm{M}$ » $\left(\mathrm{r}_{\mathrm{tt}}=0,989\right)$, «Квачі» $\left(\mathrm{r}_{\mathrm{tt}}=0,96\right)$, «Комплексний тест» $\left(\mathrm{r}_{\mathrm{tt}}=0,979\right)$.

Добра надійність спостерігалась у тестах «Стрибки 3 «надбавками» $\left(\mathrm{r}_{\mathrm{tt}}=0,92\right)$, «Стійка на одній нозі з закритими очима» $\left(\mathrm{r}_{\mathrm{tt}}=0,937\right)$, «Дзеркало» $\left(\mathrm{r}_{\mathrm{tt}}=0,926\right)$, «Нанесення на швидкість бокових ударів ногами по ракетках 3 партнером оббігаючи конуси «змійкою» $\left(\mathrm{r}_{\mathrm{tt}}=0,934\right)$.

Поганою надійністю характеризувався тест « Вправи на поєднання рухів руками, тулубом, ногами» $\left(\mathrm{r}_{\mathrm{tt}}=0,748\right)$.

\section{Дискусія}

Припускалося, що запропонована нами батарея тестів усебічно характеризує розвиток координації хлопчиків 8 років. У результаті аналізу кореляційної залежності між тестовими завданнями встановлено їх високу валідність.

Процедура «тест-ретест» дозволила перевірити надійність, стійкість результатів координаційних здібностей. Отримані коефіцієнти кореляції між результатами двох вимірювань свідчать про наявність синхронних змін ознак у вибірці.
Підтверджено знання про необхідність таких важливих характеристик, як інформативність та надійність, для вірного використання будь-яких тестів (Заціорським, 1982; Chaabène, Hachana, Franchini, Mkaouer, Montassar, \& Chamari, 2012). Дані аспекти були враховані в батареї тестів.

Наведені дані доповнюють результати дослідження про рівень фізичної підготовленості школярів молодших класів (Худолій \& Іващенко, 2014; Марченко \& Захарова, 2015; Ma \& Qu, 2017). Про важливе значення координації в структурі фізичної підготовленості дітей, які практикують спортивні одноборства і бойові мистецтва (Рогожников, 2016; Никитенко, 2018).

Наше дослідження підтверджує висновки Мa \& Qu (2017), Alesi et al. (2014) про те, що існує взаємозв'язок між фундаментальними руховими навичками і технікою карате та заняттями карате і показниками координації дітей, яка є підгрунтям для навчання фізичним вправам (Марченко \& Диханова, 2019; Styriak, Billman, Augustovicova, 2020; Марченко \& Коваленко, 2020).

Підтверджено і розширено уявлення про необхідність удосконалення системи оцінювання рухової підготовленості школярів і необхідність здійснення комплексного контролю (Карпеев, 2008; Сергієнко \& Шарий, 2010).

\section{Висновки}

Огляд існуючих підходів що до розробки критеріїв оцінки координаційних здібностей указує на те, що в їх основі лежить розробка специфічних тестів, яка включає перевірку надійності і валідності.

При визначенні координаційних здібностей спостерігається прагнення використовувати комплексні тести, які відображають характерну для каратистів рухову діяльність. В цьому випадку вирішується і проблема заощадження часу тестування. 
Отримані дані дають підставу стверджувати, що обране комплексне тестування рівня розвитку проявів координаційних здібностей хлопчиків 8 років під час занять карате $є$ доступним, інформативним та надійним, що дає можливість їх рекомендувати для подальшого дослідження в процесі вдосконалення рухової координації.

\section{Конфлікт інтересів}

Автори заявляють про відсутність конфлікту інтересів.

\section{Література}

Додаток 2 до наказу Міністерства молоді та спорту України 17.01.2015 № 67 (в редакції наказу Міністерства молоді та спорту України 10.11.2017 № 4706). http://search. ligazakon.ua/1_doc2.nsf/link1/RE31551.html

Malina, R.M. (2010). Early sport specialization: roots, effectiveness, risks. Current Sports Medicine Reports, 9(6), 364-371. https://doi.org/10.1249/JSR.0b013e3181fe3166

Jayanthi, N., Pinkham, C., Dugas, L., Patrick, B., \& LaBella, C. (2013). Sports Specialization in Young Athletes: EvidenceBased Recommendations. Sports Health, 5(3), 251-257. https://doi.org/10.1177/1941738112464626

Платонов, В.Н. (2015). Перетренированность в спорте. Наука в олимпийском спорте, (1), 19-34. http://nbuv.gov.ua/UJRN/NOS_2015_1_5

Chaabene, H., Hachana, Y., Franchini, E., Mkaouer, B., Chamari, K. (2012). Physical and physiological profile of elite karate athletes. Sports Medicine, 42(10), 829-843. https://doi.org/10.2165/11633050-000000000-00000

Slovensky zvaz karate (2017). Sutazne pravidla Slovenskeho zvazu karate k disciplinne Karate Agility ucinne od 1.2.2017. Slovak Karate Union, 2-7. Available at: http://www. karate.sk/880/karate-agility

Зациорский, В.М. (1982). Спортивная метрология: учеб. для ин-тов физ. культ. / под ред. проф. В.М. Зациорского. М.: Физкультура и спорт, 256.

Chaabène, H., Hachana, Y., Franchini, E., Mkaouer, B., Montassar, M., \& Chamari, K. (2012). Reliability and construct validity of the karate-specific aerobic test. $J$ Strength Cond Res., 26(12), 3454-3460. https://doi.org/10.1519/JSC.0b013e31824eddda

Hopkins, W.G. (2000). Measures of reliability in sports medicine and science. Sports Medicine, 30(1), 1-15. http://www.sportsci.org/resource/stats/Hopkins_ SportsMed_rely_00.pdf

Сергієнко, Л.П. (2010). Спортивна метрологія : теорія $i$ практичні аспекти. К.: КНТ, 776.

Худолій, О.М., \& Іващенко, О.В. (2011). Педагогічна практика в школі. Повідомлення II. Теорія та методика фізичного виховання, (9), 19-32. https://doi.org/10.17309/tmfv.2011.9.740 (in Ukrainian)

Худолій, О.М., \& Іващенко, О.В. (2014). Моделювання процесу навчання та розвитку рухових здібностей у дітей і підлітків: Монографія. Харків: ОВС, 320.

Марченко, C.I., \& Захарова, Є.Г. (2015). Педагогічні умови розвитку координації у дівчат молодшого шкільного віку засобами ритмічної гімнастики. Теорія та методика фізичного виховання, (2), 3-9. https://doi.org/10.17309/tmfv.2015.2.1135

Ma, A.W.W., \& Qu, L.H. (2017). Effects of Karate Training on Basic Motor Abilities of Primary School Children. Advances in Physical Education, (7), 130-139. https://doi.org/10.4236/ape.2017.72012

\section{References}

Dodatok 2 do nakazu Ministerstva molodi ta sportu Ukrainy 17.01.2015 № 67 (v redaktsii nakazu Ministerstva molodi ta sportu Ukrainy 10.11.2017 № 4706). http://search. ligazakon.ua/l_doc2.nsf/link1/RE31551.html

Malina, R.M. (2010). Early sport specialization: roots, effectiveness, risks. Current Sports Medicine Reports, 9(6), 364-371. https://doi.org/10.1249/JSR.0b013e3181fe3166

Jayanthi, N., Pinkham, C., Dugas, L., Patrick, B., \& LaBella, C. (2013). Sports Specialization in Young Athletes: EvidenceBased Recommendations. Sports Health, 5(3), 251-257. https://doi.org/10.1177/1941738112464626

Platonov, V.N. (2015). Peretrenirovannost v sporte. Nauka $v$ olimpiiskom sporte, (1), 19-34. http://nbuv.gov.ua/UJRN/NOS_2015_1_5

Chaabene, H., Hachana, Y., Franchini, E., Mkaouer, B., Chamari, K. (2012). Physical and physiological profile of elite karate athletes. Sports Medicine, 42(10), 829-843. https://doi.org/10.2165/11633050-000000000-00000

Slovensky zvaz karate (2017). Sutazne pravidla Slovenskeho zvazu karate k discipline Karate Agility ucinne od 1.2.2017. Slovak Karate Union, 2-7. Available at: http://www. karate.sk/880/karate-agility

Zatciorskii, V.M. (1982). Sportivnaia metrologiia: ucheb. dlia in-tov fiz. kult. / pod red. prof. V.M. Zatciorskogo. M. Fizkultura i sport, 256.

Chaabène, H., Hachana, Y., Franchini, E., Mkaouer, B., Montassar, M., \& Chamari, K. (2012). Reliability and construct validity of the karate-specific aerobic test. $J$ Strength Cond Res., 26(12), 3454-3460. https://doi.org/10.1519/JSC.0b013e31824eddda

Hopkins, W.G. (2000). Measures of reliability in sports medicine and science. Sports Medicine, 30(1), 1-15. http://www.sportsci.org/resource/stats/Hopkins_ SportsMed_rely_00.pdf

Serhiienko, L.P. (2010). Sportyvna metrolohiia : teoriia i praktychni aspekty. K.: KNT, 776.

Khudolii, O.M., \& Ivashchenko, O.V. (2011). Pedahohichna praktyka v shkoli. Povidomlennia II. Teoriâ ta Metodika Fizičnogo Vihovannâ, (9), 19-32. https://doi.org/10.17309/tmfv.2011.9.740 (in Ukrainian)

Khudolii, O.M., \& Ivashchenko, O.V. (2014). Modeliuvannia protsesu navchannia ta rozvytku rukhovykh zdibnostei $u$ ditei i pidlitkiv: Monohrafiia. Kharkiv: OVS, 320. (in Ukrainian)

Marchenko, S.I., \& Zakharova, Ye.H. (2015). Pedahohichni umovy rozvytku koordynatsii u divchat molodshoho shkilnoho viku zasobamy rytmichnoi himnastyky. Teoriâ ta Metodika Fizičnogo Vihovannâ, (2), 3-9. https://doi.org/10.17309/tmfv.2015.2.1135 (in Ukrainian)

Ma, A.W.W., \& Qu, L.H. (2017). Effects of Karate Training on Basic Motor Abilities of Primary School Children. 
Рогожников, М.А. (2016). Обучение юных тхэквондистов безопорным сложнокоординационным техническим действиям: автореф. дис. на соиск. уч. степени канд. пед. наук : 13.00.04. - теория и методика физического воспитания, спортивной тренировки, оздоровительной и адаптивной физической культуры / М.А. Рогожников. Санкт-Петербург, 2016. 23 с.

Никитенко, А. (2018). Тестирование ловкости и координации в спортивных единоборствах и боевых искусствах. Наука в олимпийском спорте, 18(3), 62-72. https://doi.org/10.32652/olympic2018.3_5

Alesi, M., Bianco, A., Padulo, J., Vella, F. P., Petrucci, M., Paoli, A., Palma, A., \& Pepi, A. (2014). Motor and Cognitive Development: The Role of Karate. Muscles, Ligaments and Tendons Journal, (4), 114-120. https://doi.org/10.11138/mltj/2014.4.2.114

Марченко, С.І., \& Диханова, А.І. (2019). Рухові здібності: особливості впливу занять волейболом на координаційну підготовленість дівчат 15 років. Теорія та методика бізичного виховання, 19(1), 23-28. https://doi.org/10.17309/tmfv.2019.1.03

Styriak, R., Billman, M., \& Augustovicova, D. (2020). Karate agility: The new competition category for children's physical development with very high test/re-test reliability. IDO MOVEMENT FOR CULTURE. Journal of Martial Arts Anthropology, 20(3), 32-37. https://doi.org/10.14589/ido.20.3.5

Марченко, С., \& Коваленко, К. (2020). Оптимізація режиму навчання техніки прямого удару ногою «має гері» в кіокушинкай карате хлопців 10 років. Журнал теорії та методології навчання, 1(1), 33-39. https://doi.org/10.17309/jltm.2020.1.05

Карпеев, А.Г. (2008). Критерии оценки двигательной координации спортивных действий. Вестник Томского государственного университета, (312), 169173.

Сергієнко, Л., \& Шарий, Д. (2010). Методологічні основи комплексного тестування у фізичному вихованні і спорті. Теорія та методика фізичного виховання, (5), 3-12. Retrieved from https://www.tmfv.com.ua/journal/ article/view/622
Advances in Physical Education, (7), 130-139. https://doi.org/10.4236/ape.2017.72012

Rogozhnikov, M.A. (2016). Obuchenie iunykh tkhekvondistov bezopornym slozhnokoordinatcionnym tekhnicheskim deistviiam: avtoref. dis. na soisk. uch. stepeni kand. ped. nauk : 13.00.04. - teoriia i metodika fizicheskogo vospitaniia, sportivnoi trenirovki, ozdorovitelnoi i adaptivnoi fizicheskoi kultury / M.A. Rogozhnikov. SanktPeterburg, 2016. 23 s. (in Russian)

Nikitenko, A. (2018). Testirovanie lovkosti i koordinatcii v sportivnykh edinoborstvakh i boevykh iskusstvakh. Nauka $v$ olimpiiskom sporte, 18(3), 62-72. https://doi. org/10.32652/olympic2018.3_5 (in Russian)

Alesi, M., Bianco, A., Padulo, J., Vella, F. P., Petrucci, M., Paoli, A., Palma, A., \& Pepi, A. (2014). Motor and Cognitive Development: The Role of Karate. Muscles, Ligaments and Tendons Journal, (4), 114-120. https://doi.org/10.11138/mltj/2014.4.2.114

Marchenko, S., \& Dykhanova, A. (2019). Motor Abilities: Peculiarities of Effects of Volleyball Training on Coordination Preparedness of Girls Aged 15. Teoriâ ta Metodika Fizičnogo Vihovannâ, 19(1), 23-28. https://doi.org/10.17309/tmfv.2019.1.03 (in Ukrainian)

Styriak, R., Billman, M., \& Augustovicova, D. (2020). Karate agility: The new competition category for children's physical development with very high test/re-test reliability. IDO MOVEMENT FOR CULTURE. Journal of Martial Arts Anthropology, 20(3), 32-37. https://doi.org/10.14589/ido.20.3.5

Marchenko, S., \& Kovalenko, K. (2020). Optimization of Teaching Boys Aged 10 Mae-Geri (Front Kick) Technique in Kyokushin Karate. Journal of Learning Theory and Methodology, 1(1), 33-39. https://doi.org/10.17309/jltm.2020.1.05 (in Ukrainian)

Karpeev, A.G. (2008). Kriterii otcenki dvigatelnoi koordinatcii sportivnykh deistvii. Vestnik Tomskogo gosudarstvennogo universiteta, (312), 169-173.

Serhiienko, L., \& Sharyi, D. (2010). Metodolohichni osnovy kompleksnoho testuvannia u fizychnomu vykhovanni i sporti. Teoriâ ta Metodika Fizičnogo Vihovannâ, (5), 3-12. Retrieved from https://www.tmfv.com.ua/journal/article/ view/622 (in Ukrainian)

\title{
ASSESSMENT OF RELIABILITY AND INFORMATIVENESS OF COORDINATION FITNESS INDICATORS OF 8-YEAR-OLD BOYS
}

\author{
Svitlana Marchenko ${ }^{1 \mathrm{ABCD}}$, Yaroslav Verdysh ${ }^{1 \mathrm{ABCD}}$
}

\author{
${ }^{1}$ H. S. Skovoroda Kharkiv National Pedagogical University
}

Authors' Contribution: A - Study design; B - Data collection; C - Statistical analysis; D - Manuscript Preparation; E - Funds Collection Report. Article: 8 p., 4 tabl., 1 fig., 22 sources.

The purpose of the study was to develop a program to test schoolchildren's coordination fitness at the initial training stage with the help of informative tests, which are available for use in general education schools.

Materials and methods. The study involved 20 8-year-old boys. The children and their parents were informed about all the features of the study and gave their consent to participate in the experiment. The following research methods were used to solve the tasks set: analysis of scientific and methodological literature, pedagogical testing, and methods of mathematical statistics for processing research results.

Results. The proposed battery of tests comprehensively characterizes the development of coordination in 8-year-old boys. The analysis of correlation dependence between the test tasks 
revealed their high validity $\left(\mathrm{r}_{\mathrm{xy}}=0.575-0.931\right.$ at $\left.\mathrm{p}<0.01\right)$. The tests that we selected have good and excellent retest reliability $\left(\mathrm{r}_{\mathrm{tt}}=0.92\right.$ 0.989). The combined test, which includes both general motor actions and karate elements, has a high degree of measurement reliability and can replace a whole battery of tests $\left(r_{t t}=0.979\right)$.

Conclusions. The obtained data give grounds to argue that the chosen comprehensive testing of the level of coordination abilities development of 8-year-old boys during karate classes is accessible, informative and reliable, which makes them advisable for further research on improving motor coordination.

Keywords: boys, coordination fitness, reliability and informativeness of tests, Kyokushin Karate.

\section{Information about the authors:}

Marchenko Svitlana: sport-svet1968@ukr.net; https://orcid.org/0000-0002-1013-9511; Department of Theory and Methodology of Physical Education, H. S. Skovoroda Kharkiv National Pedagogical University, Alchevskykh St, 29, Kharkiv, 61002, Ukraine.

Verdysh Yaroslav: ykropuazzz@gmail.com; https://orcid.org/0000-0002-3391-0655; Department of Theory and Methodology of Physical Education, H. S. Skovoroda Kharkiv National Pedagogical University, Alchevskykh St, 29, Kharkiv, 61002, Ukraine.

Cite this article as: Marchenko, S., \& Verdysh, Ya. (2021). Assessment of Reliability and Informativeness of Coordination Fitness Indicators of 8-Year-Old Boys. Journal of Learning Theory and Methodology, 1(2), 21-28. https://doi.org/10.17309/jltm.2021.1.03 Received: 27.11.2020. Accepted: 20.02.2021. Published: 28.02.2021

This work is licensed under a Creative Commons Attribution 4.0 International License (http://creativecommons.org/licenses/by/4.0). 